\title{
Application of the q-factor Model to the Japanese Share Market
}

\author{
Brooke Alexandra Maeda ${ }^{1}$ \\ ${ }^{1}$ School of Economics, Osaka University, Osaka, Japan \\ Correspondence: Brooke Alexandra Maeda, Graduate School of Economics, Osaka University, 1-7 \\ Machikaneyama, Toyonaka, Osaka 560-0043, Japan. E-mail: u671553j@ecs.osaka-u.ac.jp
}

Received: March 24, 2017

Accepted: April 17, 2017

Online Published: May 5, 2017

doi:10.5539/ijef.v9n6p15

URL: https://doi.org/10.5539/ijef.v9n6p15

\begin{abstract}
This paper tests the performance of the q-factor model proposed by Hou et al. (2015) to the Japanese share market. It examines ten years of monthly data for shares listed on both the First section and Second section of the Tokyo Stock Exchange. The results suggest that the q-factor model does not adequately explain returns for shares listed on the Tokyo Stock Exchange. For comparison purposes the data sample is applied to the Fama French three-factor model. The results of this analysis suggest that the Fama French three-factor model is more appropriate for the Japanese share market, and it provides evidence of a strong value premium. The factor which correlates to the value factor in the q-factor model was not significant, providing stronger support against the $\mathrm{q}$-factor model as an adequate asset pricing model for Japan.
\end{abstract}

Keywords: share returns, asset pricing

\section{Introduction}

Researchers are continually attempting to create a model which improves on the performance of past models, and is more accurate in explaining share returns. Recently Fama and French (2015) proposed a five-factor model, which adds the two new factors of investment and profitability onto the original three factor model. Similarly, Hou, Xue, and Zhang (2015) proposed a four-factor model which includes a market factor, size factor, investment factor and a profitability factor. Research which applies data to test the performance of such models has shown that both models work well on the American share market.

It is well known that the Japanese share market differs from the American share market and other international share markets, especially with regards to the trading rules. Previous research which applies asset pricing models to the Japanese share market has often produced different results to research which focuses on other major markets. Research on the CAPM model has proved that this model is inappropriate for the Japanese market (Yonezawa \& Hin, 1992; Walid \& Ahlem, 2009b). While many researchers have drawn the conclusion that momentum does not exist in Japan, Bretschger and Lechthaler (2012) found that the Carhart four-factor model performs reasonably well. Research on the Fama French three-factor model has produced mixed results, however the Fama French three-factor model is often employed as the standard asset pricing model for Japanese shares. Research by Kubota and Takehara (1997) and Bretschger and Lechthaler (2012) showed that the model is appropriate for the Japanese market, whereas Daniel, Titman, and Wei (2001) and Walid and Ahlem (2009b) present evidence which rejects the model.

Research which tests the performance of asset pricing models has produced mixed results, however evidence of a strong value effect in Japan has continually been documented. Chan, Hamao and Lakonishok (1992) found that the book to market ratio was one of two variables which has the most significant impact on share returns. More recent research by Walid (2009a) and Walid and Ahlem (2009b), showed that the book to market ratio is significantly related to average returns. Furthermore, Daniel, Titman and Wei (2001), Fama and French (2012), and Fama and French (2015b) have all documented that the value premium is strong in Japan.

Kubota and Takehara (2017) tested the plausibility of the Fama French five-factor model, recently proposed by Fama and French, to determine whether the model is appropriate for the Japanese share market. The research employs data from both the First section and Second section of the Tokyo Stock Exchange for the timeframe of January 1977 to December 2014. They conclude that the five-factor model is not a good benchmark pricing model for Japanese shares, and the two new factors of profitability (RMW) and investment (CML) are very weakly associated with the cross-sectional variation of share returns. 
The main aim of this paper is to test the performance of the q-factor model, developed by Hou, Xue, and Zhang (2015), on the Japanese share market. To the best of the authors' knowledge, there are no papers which test the performance of the q-factor model on any Japanese market. Shares listed on both the First section and Second section of the Tokyo Stock Exchange are analyzed for the ten-year sample period of 2000 to 2010. At present, the Fama French three-factor model is generally considered to be the benchmark pricing model for Japanese shares. This model is also analyzed using the same data sample to compare the results to the q-factor model and assist in determining if the q-factor model is appropriate for the Japanese share market.

The remainder of the paper is organized as follows. Section 2 discusses the q-factor model and section 3 describes the data and the methodology used to calculate the factors and portfolios. Section 4 discusses the empirical results of the sorted portfolios. Section 5 examines the Fama French three-factor model and the test results from replicating the model, while Section 6 concludes the paper.

\section{The q-factor Model}

Hou et al. (2015) proposed a q-factor model with four factors to explain share returns. They state that most of the anomalies that the Fama French three-factor model cannot explain, can be captured by this model. The model states that the expected excess return of an asset is described by the sensitivities of its returns to the market factor, size factor, investment factor and a profitability factor.

$$
E\left[r^{i}\right]-r^{f}=\beta_{M K T}^{i} E[M K T]+\beta_{M E}^{i} E\left[r_{M E}\right]+\beta_{I / A}^{i} E\left[r_{I / A}\right]+\beta_{R O E}^{i} E\left[r_{R O E}\right]
$$

in which $\mathrm{E}[\mathrm{MKT}], \mathrm{E}\left[\mathrm{r}_{\mathrm{ME}}\right], \mathrm{E}\left[\mathrm{r}_{\mathrm{I} / \mathrm{A}}\right], \mathrm{E}\left[\mathrm{r}_{\mathrm{ROE}}\right]$ are the expected factor premiums, and $\beta_{\mathrm{MKT}}^{\mathrm{i}}, \beta_{\mathrm{ME}}^{\mathrm{i}}, \beta_{\mathrm{I} / \mathrm{A}}^{\mathrm{i}}$ and $\beta_{\mathrm{ROE}}^{\mathrm{i}}$ are the factor loadings on MKT, $r_{\mathrm{ME}}, \mathrm{r}_{\mathrm{I} / \mathrm{A}}$, and $\mathrm{r}_{\mathrm{ROE}}$ respectively. The market factor (MKT) is the market excess return. The size factor $\left(\mathrm{r}_{\mathrm{ME}}\right)$ is the difference between the return on a portfolio of small size shares and the return on a portfolio of big size shares. The investment factor $\left(\mathrm{r}_{\mathrm{I} / \mathrm{A}}\right)$ is the difference between the return on a portfolio of low investment shares and the return on a portfolio of high investment shares. Lastly, the profitability factor $\left(\mathrm{r}_{\mathrm{ROE}}\right)$ is the difference between the return on a portfolio of shares with high return on equity and the return on a portfolio of shares with low return on equity. This model is partly inspired by investment-based asset pricing as the neoclassical q-theory of investment states that ROE forecasts returns to the extent that it forecasts future ROE.

\section{Factors}

\subsection{Data Description}

This study examines monthly data for shares listed on both the First section and Second section of the Tokyo Stock Exchange, from October 2000 to September 2010 (10 years). The data comes from two sources. The monthly share prices, risk-free rate and all accounting data are collected from the Nikkei Economic Databank System database (NEEDS). The market returns for the universe of the First section and Second section of the Tokyo Stock Exchange are collected from "Kubota and Takehara's Fama-French data related to the listed Japanese stocks". The returns for the universe are utilized as the market return, as this study combines shares from both the First section and Second section of the stock exchange.

The sample includes all shares listed on both sections of the Tokyo Stock Exchange, however financial firms and utilities have been excluded. Also, firms with data missing for any of the factors have been excluded from the sample.

The methodology of Hou et al. (2015) is followed by forming test portfolios based on size, the investment factor and profitability factor. Two adjustments were made from the original methodology to apply the model to the Japanese share market. Firstly, to ensure that the accounting data is publicly available at the time of portfolio formation, we formed portfolios at the beginning of October. Japanese companies have March as the end of their fiscal year, and release accounting information before September. Forming portfolios on the first of October ensures that all data is available. Other researchers such as Daniel, Titman, and Wei (2001), and Walid (2009) have utilized this methodology when analyzing the Japanese share market. The portfolios are formed on the first of October and held for one year. The market size (size factor) is the market equity at the end of September. It is calculated as the share price times the number of shares issued, at the end of September. The second adjustment to the methodology of Hou et al. (2015) is the method used to calculate the profitability factor. Hou et al. (2015) utilized quarterly data, however most firms in Japan do not release quarterly figures. Due to data limitations, annual data is utilized for the return on equity (ROE) figures.

\subsection{Factor Construction}

The size, investment and ROE factors are constructed from a triple sort $(2 \times 3 \times 3)$ on size, investment-to-assets 
and ROE. Size is the market equity at the end of September. The investment factor (I/A) is the annual change in total assets divided by one-year-lagged total assets. The profitability factor (ROE) is the income before extraordinary items divided by lagged book equity.

At the end of September each year, shares are split into two groups, big and small, based on the market equity. Independently, at the end of September, shares are sorted into three groups based on the I/A data from the previous year, using the breakpoints of 30\%, $40 \%$ and 30\%. In addition, shares are sorted into three groups based on the ROE data for the previous year, using the breakpoints of $30 \%, 40 \%$ and $30 \%$. Taking the intersections of the two size groups, 3 I/A groups and 3 ROE groups, creates 18 portfolios. The portfolios are constructed at the end of September and held for one year.

These portfolios are used to calculate the factor returns needed for the regressions. The size factor $\left(\mathrm{r}_{\mathrm{ME}}\right)$ is the difference between the simple average of the 9 small portfolio returns and the simple average of the 9 big portfolio returns. The investment factor $\left(\mathrm{r}_{\mathrm{I} / \mathrm{A}}\right)$ is the difference between the simple average of the 6 low I/A portfolios and the simple average of the 6 high I/A portfolios. Similarly, the profitability factor $\left(\mathrm{r}_{\mathrm{ROE}}\right)$ is the difference between the 6 high ROE portfolios and the 6 low ROE portfolios. The market portfolio contains all the shares.

\section{Empirical Results}

\subsection{Return Patterns of Sorted Portfolios}

As previously explained, the q-factor model sorts shares based on size, investment and ROE, and forms 18 portfolios. The portfolios are created at the end of September and held for one year. The descriptive statistics for the 18 portfolios are detailed in Table 1. The number of shares in each portfolio varies and changes after the annual reconstruction. The two extreme portfolios, that is small size, low I/A, low ROE portfolio, and the big size, high I/A, high ROE portfolio have the largest average number of shares in the portfolio.

Table 1. Descriptive statistics for the 18 sorted portfolios formed on size, I/A and ROE: October 2000 to September 2010 (10 years)

\begin{tabular}{|c|c|c|c|c|c|c|}
\hline \multicolumn{7}{|c|}{ Average of annual number of firms in the portfolio } \\
\hline \multirow[b]{2}{*}{$\mathrm{I} / \mathrm{A}$} & \multicolumn{3}{|c|}{ Small } & \multicolumn{3}{|c|}{ Big } \\
\hline & Low 1 & 2 & 3 & Low 1 & 2 & 3 \\
\hline \multicolumn{7}{|l|}{ ROE } \\
\hline Low 1 & 164.6 & 108.3 & 43.1 & 76 & 71 & 29.2 \\
\hline 2 & 71.6 & 124.5 & 69.5 & 67.3 & 151.5 & 79.5 \\
\hline 3 & 37.5 & 58.2 & 85 & 40.2 & 136.3 & 151.7 \\
\hline \multicolumn{7}{|c|}{ Average of annual averages of firm size for portfolio } \\
\hline & \multicolumn{3}{|c|}{ Small } & \multicolumn{3}{|c|}{ Big } \\
\hline $\mathrm{I} / \mathrm{A}$ & Low 1 & 2 & 3 & Low 1 & 2 & 3 \\
\hline \multicolumn{7}{|l|}{ ROE } \\
\hline Low 1 & 10171823740 & 10843793373 & 11339145224 & $2.06566 \mathrm{E}+11$ & $2.14135 \mathrm{E}+11$ & 3.34599E+11 \\
\hline 2 & 11904466226 & 12856572823 & 12693273692 & $2.89155 \mathrm{E}+11$ & $2.44278 \mathrm{E}+11$ & $2.57158 \mathrm{E}+11$ \\
\hline 3 & 11611850827 & 12343528252 & 13501234233 & $4.61803 \mathrm{E}+11$ & $4.278 \mathrm{E}+11$ & $5.61842 \mathrm{E}+11$ \\
\hline \multicolumn{7}{|c|}{ Average of annual ROE ratios for portfolio } \\
\hline & \multicolumn{3}{|c|}{ Small } & \multicolumn{3}{|c|}{ Big } \\
\hline $\mathrm{I} / \mathrm{A}$ & Low 1 & 2 & 3 & Low 1 & 2 & 3 \\
\hline \multicolumn{7}{|l|}{ ROE } \\
\hline Low 1 & -19.11904 & -6.15598 & -8.52913 & -15.37979 & -3.26631 & -8.24618 \\
\hline 2 & 4.74111 & 4.80596 & 5.11897 & 4.79516 & 5.03537 & 5.31748 \\
\hline 3 & 78.39574 & 13.85253 & 15.36731 & 14.82433 & 12.14065 & 14.98422 \\
\hline \multicolumn{7}{|c|}{ Average of annual I/A ratios for portfolio } \\
\hline & \multicolumn{3}{|c|}{ Small } & \multicolumn{3}{|c|}{ Big } \\
\hline $\mathrm{I} / \mathrm{A}$ & Low 1 & 2 & 3 & Low 1 & 2 & 3 \\
\hline \multicolumn{7}{|l|}{ ROE } \\
\hline Low 1 & -0.10389 & 0.00500 & 0.17505 & -0.08659 & 0.00623 & 0.16592 \\
\hline 2 & -0.07625 & 0.01213 & 0.15168 & -0.06240 & 0.01118 & 0.13452 \\
\hline 3 & -0.09544 & 0.01335 & 0.20515 & -0.07497 & 0.01642 & 0.19236 \\
\hline
\end{tabular}


Table 2 presents the mean monthly excess returns for the 18 sorted portfolios for the ten year period. The mean monthly excess returns are all negative, which reflects the movement of the share market during the sample period. The movement of the indices for both the First section and Second section are shown in Figure 1. The return marginally decreases as the size and I/A values increase, with a maximum of a $0.009 \%$ lower return. In the $\mathrm{q}$-factor model, the investment factor correlates to the value premium, and the profitability factor correlates to the momentum factor. A marginally decreasing return as I/A increases, suggests that a value effect may possibly exist.

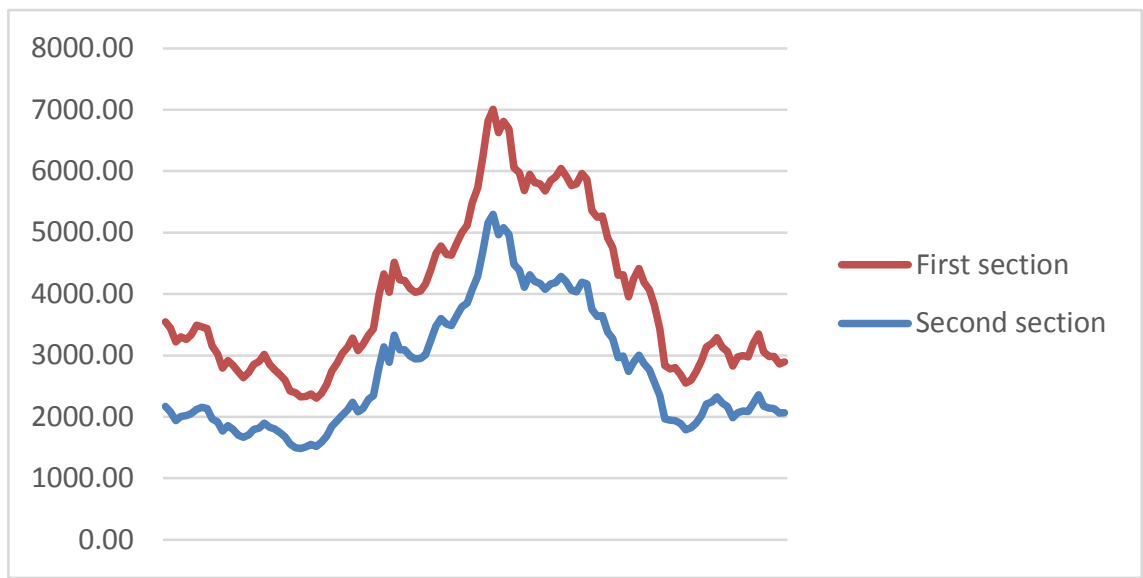

Figure 1. Movement of the Tokyo stock exchange indices, October 2000 - September 2010

Table 2. Mean monthly excess returns (in percent) on the 18 sorted portfolios: October 2000 to September 2010 (120 months)

\begin{tabular}{|c|c|c|c|c|c|c|}
\hline \multicolumn{4}{|c|}{ Small } & \multicolumn{3}{|c|}{ Big } \\
\hline I/A & Low 1 & 2 & 3 & Low 1 & 2 & 3 \\
\hline \multicolumn{7}{|l|}{ ROE } \\
\hline Low 1 & -0.116688 & -0.117103 & -0.115741 & -0.11817 & -0.11941 & -0.121211 \\
\hline 2 & -0.117164 & -0.118558 & -0.11818 & -0.119218 & -0.119614 & -0.122339 \\
\hline 3 & -0.119639 & -0.117558 & -0.120002 & -0.121895 & -0.122966 & -0.124993 \\
\hline
\end{tabular}

Size is price per share times shares outstanding. Investment-to-assets (I/A) is the annual change in total assets divided by lagged total assets. Return on equity (ROE) is income before extraordinary items divided by book equity. At the end of September of each year $t$, we use the median size at the end of September to split the shares listed on the First section and Second section into 2 groups, big and small. Independently, at the end of September of each year $t$, we also sort shares into $3 \mathrm{I} / \mathrm{A}$ groups, using the breakpoints of $30 \%, 40 \%$ and $30 \%$ based on the financial data for year $t-1$. In addition, we independently sort shares into 3 ROE groups using the breakpoints of $30 \%, 40 \%$ and $30 \%$ based on the financial data for year $t-1$. Taking the intersection of the 2 size groups, 3 I/A groups and 3 ROE groups, we form 18 portfolios. The monthly value-weighted returns for the 18 portfolios are calculated.

\section{2 q-factor Tests}

To test the performance of the q-factor model on the Japanese share market, we construct factor returns and factor portfolios as explained in section 2.2. Table 3 reports the intercepts and t statistics for the 18 sorted portfolios. The average magnitude of the intercepts is -0.11526 . The $t$ statistics for all the portfolios is greater than 2, which suggests that this model is not appropriate to explain share returns on the Japanese share market. Research on the American share market by Hou et al. (2015) showed that the investment factor provided most of the model`s good performance. The results in Table 3 suggest that this is not the case in Japan. Furthermore, the investment factor earns an average return of $0.0838 \%$, whereas the size factor earns $0.2918 \%$ and the profitability factor earns $-0.312 \%$. Overall the results suggest that neither the investment factor or the profitability factor as defined in the q-factor model are significant. 
Table 3. Time series regression of the 18 sorted portfolios: October 2000 to September 2010 (120 months)

\begin{tabular}{|c|c|c|c|c|c|c|}
\hline \multicolumn{7}{|c|}{ Panel A: Intercept Estimates from the q-factor model } \\
\hline \multicolumn{4}{|c|}{ Small } & \multicolumn{3}{|c|}{ Big } \\
\hline I/A & Low 1 & 2 & 3 & Low 1 & 2 & 3 \\
\hline \multicolumn{7}{|l|}{ ROE } \\
\hline Low 1 & -0.11733 & -0.11651 & -0.11724 & -0.11461 & -0.11365 & -0.11566 \\
\hline 2 & -0.11532 & -0.11559 & -0.11344 & -0.1135 & -0.11308 & -0.11471 \\
\hline 3 & -0.11865 & -0.11323 & -0.11568 & -0.11618 & -0.11511 & -0.11512 \\
\hline \multicolumn{7}{|c|}{ Panel B: $\mathrm{t}$ Statistics from the q-factor model } \\
\hline \multicolumn{4}{|c|}{ Small } & \multicolumn{3}{|c|}{ Big } \\
\hline I/A & Low 1 & 2 & 3 & Low 1 & 2 & 3 \\
\hline \multicolumn{7}{|l|}{ ROE } \\
\hline Low 1 & -2.18403 & -2.20445 & -2.1829 & -2.09431 & -2.09254 & -2.03711 \\
\hline 2 & -2.20229 & -2.14049 & -2.11981 & -2.04447 & -2.05792 & -2.06388 \\
\hline 3 & -2.19688 & -2.09684 & -2.14539 & -2.15205 & -2.06815 & -2.05839 \\
\hline
\end{tabular}

The formation of the 18 sorted portfolios is described in Table 2. The construction of the size factor portfolio, the I/A factor portfolio, and the ROE factor portfolio is as follows. The size factor $R_{m e}$ is the difference each month between the simple average of the 9 small portfolio returns and the simple average of the 9 big portfolio returns. The investment factor, $R_{\mathrm{I} / \mathrm{A}}$, is the difference between the simple average of the 6 low I/A portfolios and the simple average of the 6 high I/A portfolios. Similarly, the profitability factor $\mathrm{R}_{\text {roe }}$ is the difference between the 6 high ROE portfolios and the 6 low ROE portfolios. A value-weighted portfolio Mkt is formed that contains all firms listed on the First section and Second section of the TSE. This table presents the intercept estimates and $\mathrm{t}$ statistics from the $\mathrm{q}$-factor model. The estimation method is ordinary least squares.

\section{The Fama French Three-Factor Model}

Previous research has produced mixed results regarding the performance of the Fama French three-factor model, however it is generally considered to be the benchmark asset pricing model for Japanese shares. In this study, the three-factor model is analyzed using the same data sample to compare the results to the q factor model and assist in determining if the $\mathrm{q}$ factor model is appropriate for the Japanese share market. The three-factor model is described as:

$$
R_{i, t}-R_{f, t}=\alpha_{i}+\beta_{i, M k t}\left(R_{M k t, t}-R_{f, t}\right)+\beta_{i, S M B}\left(R_{S M B, t}\right)+\beta_{i, H M L}\left(R_{H M L, t}\right)+e_{i, t}
$$

where $R_{\mathrm{i}, \mathrm{t}}$ is the return on asset I for month $t, \mathrm{R}_{\mathrm{f}, \mathrm{t}}$ is the riskfree rate, $\mathrm{R}_{\mathrm{Mkt}, \mathrm{t}}-\mathrm{R}_{\mathrm{f}, \mathrm{t}}$ is the excess market return, $\mathrm{R}_{\mathrm{SMB}, \mathrm{t}}$ is the realized return on the size-factor portfolio and $\mathrm{R}_{\mathrm{HML}, \mathrm{t}}$ is the realized return on the book-to-market portfolio. We have followed the methodology of the q-factor model as much as possible, to ensure accurate comparisons between the models. At the end of September all shares are ranked on their book-to-market and size, independently, and the $20 \%, 40 \%, 60 \%$ and $80 \%$ breakpoints are used to sort the shares into five equal groups. Sorting shares into five size groups and five book-to-market groups, creates 25 portfolios. The portfolios are created at the end of September and held for one year.

Table 4 presents the mean monthly excess returns for the 25 size and book-to-market sorted portfolios. The bottom row and right-most column report the differences between the average returns of the smallest and largest shares, and the differences between the highest and lowest book-to-market shares. As size increases the average return decreases slightly, and as book-to-market increases the average return increases slightly. The average size effect across the five groups is $-0.02428 \%$, and the average book-to-market effect is $-1.0636 \%$. These results demonstrate the existence of a significantly strong book-to-market effect in the Japanese share market.

To replicate the Fama French tests we created factor portfolios. To form the portfolios, shares are ranked according to size and book-to-market values, and portfolios are constructed using the $30 \%$ and $70 \%$ breakpoints for book-to-market and 50\% for size. Shares below the 30\% breakpoint for book-to-market values are designated $\mathrm{L}$, the middle $40 \%$ of firms are designated $\mathrm{M}$, and the shares above the $70 \%$ breakpoint are designated $\mathrm{H}$. Firms above the 50\% size breakpoint are designated $\mathrm{B}$ and the remaining $50 \%$ are designated $\mathrm{S}$. These rankings allow us to form six value-weighted portfolios: $\mathrm{L} / \mathrm{S}, \mathrm{M} / \mathrm{S}, \mathrm{H} / \mathrm{S}, \mathrm{L} / \mathrm{B}, \mathrm{M} / \mathrm{B}$ and H/B. From these six portfolio returns, we calculate the HML factor portfolio returns, which are defined as $R_{H M L}=\left(R_{H B}+R_{H S}-R_{L B}-R_{L S}\right) / 2$, and the $S M B$ factor portfolio returns, which are defined as $R_{S M B}=\left(R_{H S}+R_{M S}+R_{L S}-R_{H B}-R_{M B}-R_{L B}\right) / 3$. A value-weighted portfolio Mkt is formed which contains all the firms in these six portfolios plus the excluded firms, in other words it contains all the shares listed on the First and Section sections of the Tokyo Stock Exchange. The regression results for the 25 portfolios are presented in Table 5, with the intercepts and t statistics from the Fama French three-factor model. 
Table 4. Mean monthly excess returns (in percent) on the 25 size and book-to-market sorted portfolios: October 2000 to September 2010 (120 months)

\begin{tabular}{|c|c|c|c|c|c|c|}
\hline & \multicolumn{4}{|c|}{ Book-to-Market } & \multirow[b]{2}{*}{ High } & \multirow[b]{2}{*}{$\mathrm{H}-\mathrm{L}$} \\
\hline & Low & & & & & \\
\hline \multicolumn{7}{|l|}{ Size } \\
\hline \multirow[t]{4}{*}{ Small } & -1.021499 & -1.056761 & -1.055158 & -1.041052 & -1.026672 & -1.055158 \\
\hline & -1.118407 & -1.099575 & -1.096864 & -1.070634 & -1.036591 & -1.096864 \\
\hline & -1.142416 & -1.08958 & -1.094882 & -1.07115 & -1.036655 & -1.094882 \\
\hline & -1.164054 & -1.09864 & -1.06324 & -1.046522 & -1.054147 & -1.06324 \\
\hline Big & -1.072778 & -1.019366 & -1.007862 & -0.961062 & -1.018673 & -1.007862 \\
\hline$S-B$ & 0.0512791 & -0.037395 & -0.047296 & -0.07999 & -0.007999 & \\
\hline
\end{tabular}

We rank all TSE firms by their book-to-market at the end of March and their market capitalization (Size) at the end of September of year t. We form 20 percent, 40 percent, 60 percent and 80 percent breakpoints for book-to-market and size based on these rankings. At the beginning of October of year $t$, firms are placed into the five book-to-market groups and the five size groups based on these breakpoints. The firms remain in these portfolios from the beginning of October of year $t$ to the end of September of year $t+1$.

Table 5. Time-series regressions of the 25 size and book-to-market sorted portfolios: October 2000 to September 2010 (120 months)

\begin{tabular}{|c|c|c|c|c|c|}
\hline & \multicolumn{4}{|c|}{ Book-to-Market } & \multirow[t]{2}{*}{ 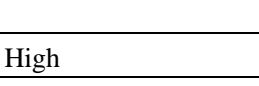 } \\
\hline & Low & & & & \\
\hline \multicolumn{6}{|l|}{ Size } \\
\hline \multirow[t]{4}{*}{ Small } & 0.0034465 & 0.0030832 & 0.002254 & 0.001925 & 0.0034786 \\
\hline & -0.001739 & 0.0015197 & -0.000767 & -0.002193 & -0.000788 \\
\hline & -0.002675 & 0.0025816 & -0.000283 & -0.002298 & 0.0009345 \\
\hline & -0.001128 & 0.0001087 & 0.004086 & -0.000672 & -0.003874 \\
\hline Big & 0.0011182 & 0.0022444 & 0.0012473 & -0.009209 & -0.002029 \\
\hline \multicolumn{6}{|c|}{ Panel B: t Statistics from the Fama-French Three-Factor Model } \\
\hline \multicolumn{6}{|l|}{ Size } \\
\hline \multirow[t]{4}{*}{ Small } & 0.6170429 & 0.9950723 & 0.6433659 & 0.8168613 & 1.4698748 \\
\hline & -0.22698 & 0.3664862 & -0.294656 & -0.956644 & -0.300556 \\
\hline & -0.380422 & 0.7493367 & -0.076245 & -0.584298 & 0.1997499 \\
\hline & -0.395389 & 0.0532685 & 0.8237679 & -0.165855 & -0.854676 \\
\hline Big & 0.8651911 & 1.175267 & 0.495544 & -1.445181 & -0.353223 \\
\hline
\end{tabular}

The formation of the 25 sorted portfolios is described in Table 4. The construction of the HML factor portfolio, SMB factor portfolio and the Mkt factor portfolio is as follows. Portfolios are constructed using the 30\% and 70\% breakpoints for book-to-market and 50\% for size. Shares below the $30 \%$ breakpoint for book-to-market values are designated L, the middle $40 \%$ of firms are designated $\mathrm{M}$, and the shares above the $70 \%$ breakpoint are designated H. Firms above the 50\% size breakpoint are designated B and the remaining $50 \%$ are designated S. From these rankings, we form the six value-weighted portfolios L/S, M/S, H/S, L/B, M/B and H/B. From these portfolio returns, we calculate the HML factor portfolio return and the SMB factor portfolio return. This table presents the intercept estimates and $t$ statistics for the Fama-French three-factor model.

The intercepts for all the portfolios are close to zero, and are lower than the intercepts in the q-factor model. Furthermore, none of the t statistics in Panel B are over 2, which suggests that it cannot be stated that this model does not do a good job of explaining returns. A comparison of the intercept estimates and t statistics from the Fama French three-factor model and the q-factor model, lead us to conclude that the Fama French model explains the cross-sectional variation of returns better.

\section{Conclusion}

This study tests the performance of the q-factor model proposed by Hou et al. (2015) on the Japanese share market. It examines monthly data of shares listed on both the First section and Second section of the Tokyo Stock Exchange for the ten-year timeframe of October 2000 to September 2010. 
The regression results on the portfolios sorted on the factors of size, investment and profitability, suggest that the q-factor model does not adequately explain share returns for the Japanese share market. In this model, the investment factor is correlated to value and the profitability factor is correlated to momentum. Previously numerous researchers have provided evidence that the value premium is significantly strong in Japan, however the analysis on the q-factor model shows that the investment factor, as defined in this model, is not significant. For comparison purposes, the same data sample and timeframe is utilized to test the performance of the Fama French three-factor model. While the analysis is limited, based on the results, we are not able to state that the model does not do a good job of explaining returns. Of the two asset pricing models, it appears that the Fama French model is more appropriate for the Japanese market.

Interestingly, the excess returns on the sorted portfolios demonstrate the existence of a significantly strong book-to-market effect, which is consistent with previous research. Daniel, Titman, and Wei (2001), Walid (2009a), Walid and Ahlem (2009b), Fama and French (2012) and Fama and French (2015b), have all demonstrated the existence of a book-to-market effect for Japanese share returns. The regression results in this paper support previous research regarding a strong value premium, yet the factor which relates to value in the $\mathrm{q}$-factor model is insignificant. This adds further support to the original portfolio regression results, that the q-factor model is not adequate for the Japanese market. The q-factor model calculates the factor based on the annual change in total assets, whereas the Fama French three-factor model defines the factor to be the book-to-market value. Interestingly, research by Kubota and Takehara (2017) which examines the Fama French five-factor model, also documents that the investment factor which is calculated the same as the value factor in the q-factor model, is not statistically insignificant. Future avenues for research may include extending the timeframe studied, or testing alternative calculation methods for the investment factor.

\section{Acknowledgements}

The author is grateful to Wataru Ohta and all members of the seminar who gave helpful comments for improving this paper.

\section{References}

Bretschger, L., \& Lechthaler, F. (2012). Common Risk Factors and the Macroeconomy: New Evidence from the Japanese Stock Market. Centre of Economic Research at ETH Zurich, Economics Working Paper Series, 12/160, pp. 1-26. http://dx.doi.org/10.2139/ssrn.2044464

Daniel, K., Titman, S., \& John Wei, K. C. (2001). Explaining the Cross-Section of Stock Returns in Japan: Factors or Characteristics? The Journal of Finance, LVI(2), 743-766. http://dx.doi.org/10.1111/0022-1082.00344

Fama, E., \& French, K. R. (1992). The cross-section of expected stock returns. Journal of Finance, 47, 427-465. http://dx.doi.org/10.1111/j.1540-6261.1992.tb04398.x

Fama, E., \& French, K. R. (1993). Common risk factors in the returns on stocks and bonds. Journal of Financial Economics, 33, 3-56. http://dx.doi.org/10.1016/0304-405X(93)90023-5

Fama, E., \& French, K. R. (1995). Size and book-to-market factors in earnings and returns. The Journal of Finance, 50(1), 131-155. http://dx.doi.org/10.1111/j.1540-6261.1995.tb05169.x

Fama, E., \& French, K. R. (2012). Size, value and momentum in international stock returns. Journal of Financial Economics, 105, 457-472. http://dx.doi.org/10.1016/j.jfineco.2012. 05.011

Fama, E., \& French, K. R. (2015a). A five-factor asset pricing model. Journal of Financial Economics, 116, 1-22. http://dx.doi.org/10.1016/j.jfineco.2014.10.010

Fama, E., \& French, K. R. (2015b). International Tests of a Five-Factor Asset Pricing Model. Fama-Miller Working Paper, Tuck School of Business Working Paper, No. 2622782. http://dx.doi.org/10.2139/ssrn.2622782

Hou, K., Xue, C., \& Zhang, L. (2014). A Comparison of New Factor Models. NBER Working Paper No. 20682, November 2014, 1-90. https://doi.org/10.3386/w20682

Hou, K., Xue, C., \& Zhang, L. (2015). Digesting anomalies: An investment approach. Review of Financial Studies, 28(3), 650-705. https://doi.org/10.1093/rfs/hhu068

Kubota, K., \& Takehara, H. (2017). Does the Fama and French Five-Factor Model Work Well in Japan? International Review of Finance. http://dx.doi.org/10.1111/irfi.12126

Walid, E. M. (2009a). New Evidence on Risk Factors, Characteristics and the Cross-Sectional Variation of 
Japanese Stock Returns. Asia-Pacific Financial Markets, $16, \quad 33-50$. http://dx.doi.org/10.1007/s10690-009-9085-5

Walid, E. M., \& Ahlem, E. M. (2009b). New Evidence on the Application of Fama and French Three-Factor Model to the Japanese Stock Market. Working Paper, Osaka University, pp. 1-13.

Yonezawa, Y., \& Hin, T. K. (1992). An empirical test of the CAPM on the stocks listed on the Tokyo Stock Exchange. Japan and the World Economy, 4, 145-161. http://dx.doi.org/10. 1016/0922-1425(92)90015-I

\section{Copyrights}

Copyright for this article is retained by the author(s), with first publication rights granted to the journal.

This is an open-access article distributed under the terms and conditions of the Creative Commons Attribution license (http://creativecommons.org/licenses/by/4.0/). 